\title{
FORMULASI SEDIAAN SIRUP PENINGKAT IMUNITAS DARI HERBA MENIRAN (Phyllanthus niruri L.)
}

\author{
W. O. Sugarda, K.D.C. Dewi, K.W.A. Putra, M.B. Yogiswara, C.B.A.C. Sukawati, P.A.R. \\ Sutresna, N.L.G.J. Dewi, C.I.S. Arisanti, P.S. Yustiantara

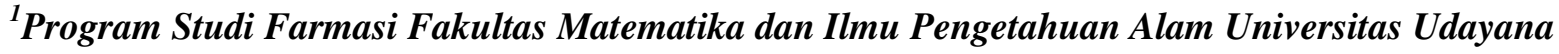 \\ Jalan Kampus Unud-Jimbaran, Jimbaran-Bali, Indonesia 80364 Telp./Fax. 703837 \\ "e-mail: okasugarda@gmail.com
}

\begin{abstract}
ABSTRAK
Herba meniran (Phyllanthus niruri L.) merupakan tanaman yang secara ilmiah telah terbukti mempunyai aktivitas sebagai imunomodulator alami. Efektivitas imunomodulator alami dari herba meniran dapat ditingkatkan dengan memformulasikan ekstrak etanol herba meniran menjadi bentuk sediaan sirup. Penelitian ini dilakukan untuk mengetahui bahwa ekstrak herba meniran yang diperoleh telah memenuhi parameter standar mutu ekstrak sehingga dapat diformulasikan menjadi produk farmasi. Standarisasi ekstrak herba meniran meliputi pengujian kadar air, pengujian kadar abu total, pengujian kadar abu larut asam, dan pengujian kadar flavonoid total. Ekstrak etanol herba meniran diperoleh dengan cara maserasi menggunakan etanol $95 \%$. Pengujian kadar air ekstrak menghasilkan ekstrak dengan kadar air sebesar 7,295\%. Kadar abu total sebesar 3\%, kadar abu tidak larut asam 1,2\% dan kadar flavonoid total sebesar 3,15\%.
\end{abstract}

Kata kunci: formulasi, imunitas, Phyllanthus niruri L., sirup

\begin{abstract}
Meniran herb (Phyllanthus niruri L.) is a plant that has been scientifically proven to have activity as a natural immunomodulator. The effectiveness of natural immunomodulators from meniran herbs can be improved by formulating the ethanolic extract of meniran herbs into syrup preparations. This research was conducted to find out that the herbal extracts obtained had fulfilled the parameters of extract quality standards so that they could be formulated into pharmaceutical products. Standardization of herbal extracts includes testing of moisture content, testing of total ash content, testing of acid-soluble ash content, and testing of total flavonoid levels. Ethanol extract of Meniran herbs was obtained by maceration using $95 \%$ ethanol. Testing the extract moisture content produced extracts with a moisture content of $7.295 \%$. Total ash content was $3 \%$, acid insoluble ash content was $1.2 \%$ and total flavonoid content was $3.15 \%$.
\end{abstract}

Keywords: formulation, immunity, syrup, Phyllanthus niruri L.

\section{PENDAHULUAN}

Sistem kekebalan tubuh (imunitas) merupakan suatu mekanisme yang digunakan tubuh untuk menangkal pengaruh faktor atau zat yang berasal dari luar tubuh (Roitt, 1990). Ada dua sumber kekebalan tubuh, yakni kekebalan alami dan adaptif (Bellanthi, 1993). Pada prinsipnya kerja sistem imun dalam menghadapi invasi bahan asing dari luar tubuh bekerja secara serempak (Mondal et al., 2011). Suseptibilitas dan resistensi hewan terhadap infeksi mikroba sangat tergantung pada aktivasi dari sel $\mathrm{ThCD}^{+}$yang berdiferensiasi menjadi 2 kelompok berdasarkan pola sekresi sitokin, yakni pola respon Th-1 dan pola respon Th-2 (Wiedosari, 2007). Sitokin merupakan protein pembawa pesan kimiawi, atau mediator komunikasi interseluler berperan mengendalikan respon imun baik pada sistem imunitas seluler maupun humoral (Tizard, 2000).

Herba meniran (Phyllanthus niruri L.). memiliki kandungan kimia flavonoid seperti kuersetin, kuersitrin, isokuersitrin, astragalin, dan rutin, serta mengandung kaempferol-1-4ramnopiranosid, eridiktol-7-ramnopiranosid, nirurin, nirurisid, filantin, hipofilantin, triterpene, dan alkaloid sekurinin yang berfungsi sebagai imunomodulator alami (Puspitasari, 2010; Ross, 1999). Pemanfaatan tanaman herba meniran sebagai imunomodulator alami dapat ditingkatkan efektivitasnya dengan memformulasikan ekstrak etanol herba meniran menjadi bentuk sediaan sirup. Sirup merupakan sediaan pekat 
dalam air dari gula atau pengganti gula dengan atau tanpa penambahan bahan pewangi dan zat obat (Ansel, 2005). Formula sirup yang digunakan dalam penelitian ini adalah propilenglikol berfungsi sebagai solven atau kosolven, nipagin sebagai pengawet dikarenakan dalam pembuatan sirup ini menggunakan sirupus simplex dengan pelarut utama air sehingga dapat dengan mudah ditumbuhi mikroba, essense anggur, dan sirupus simplex (Rowe et al., 2009).

Dalam upaya meningkatkan penerimaan masyarakat terhadap obat herbal, maka diperlukan pengembangan obat tradisional menjadi fitofarmaka. Fitofarmaka adalah sediaan obat yang telah dibuktikan keamanan dan khasiatnya, bahan bakunya terdiri dari simplisia atau sediaan galenik yang telah memenuhi persyaratan yang berlaku (Menkes RI, 1994). Bahan baku harus memenuhi persyaratan yang tertera dalam Farmakope Indonesia, Ekstra Farmakope Indonesia atau Materia Medika Indonesia/Bila pada ketiga buku persyaratan tersebut tidak tertera paparannya, boleh menggunakan ketentuan dalam buku persyaratan mutu negara lain atau pedoman lain (DepKes RI, 1992).

Ekstrak herba meniran yang akan digunakan dalam pembuatan produk farmasi perlu dilakukan standarisasi ekstrak untuk mengetahui bahwa ekstrak yang diperoleh telah memenuhi parameter standar mutu ekstrak. Standarisasi adalah rangkaian proses yang melibatkan berbagai metode analisis kimiawi berdasarkan data farmakologis, melibatkan analisis fisik dan mikrobiologi berdasarkan kriteria umum keamanan (toksikologi) terhadap suatu ektrak alam (Sjahrurachman dkk., 2004). Standarisasi ekstrak meliputi uji kadar air yang merupakan pengukuran kandungan air yang berada didalam bahan, yang bertujuan untuk memberikan batasan minimal atau rentang tentang besarnya kandungan air dalam bahan (DepKes RI, 2000); uji kadar abu total dimana bahan dipanaskan pada temperature dimana senyawa organik dan turunanya terdestruksi dan menguap sehingga tinggal unsur mineral dan anorganik yang memberikan gambaran kandungan mineral internal dan eksternal yang berasal dari proses awal sampai terbentuknya ekstrak, parameter kadar abu ini terkait dengan kemurnian dan kontaminasi suatu ekstrak (DepKes RI, 2000); uji kadar abu tidak larut asam dan uji kadar flavonoid total.

\section{BAHAN DAN METODE}

\section{Bahan}

Bahan yang digunakan adalah Herba meniran (Phyllanthus niruri L.)., Sukrosa, Propilenglikol, Nipagin, Essence Anggur dan Aquades.

\section{Formula Sirup Herba Meniran}

Pada penelitian ini formula yang digunakan adalah sebagai berikut :

Tabel 1. Formula Sirup Herba Meniran

\begin{tabular}{ll}
\hline \multicolumn{1}{c}{ Bahan } & \multicolumn{1}{c}{ Konsentrasi Bahan } \\
& Penyusun Sediaan \\
\hline Ekstrak Herba Meniran & $4,8 \mathrm{~g}$ \\
Propilenglikol & $12 \mathrm{~g}$ \\
Nipagin & $0,24 \mathrm{~g}$ \\
Essense Anggur & $0,3 \mathrm{~g}$ \\
Sirup Simpleks & ad. $60 \mathrm{~mL}$ \\
\hline
\end{tabular}

\section{Ekstraksi Herba Meniran}

Serbuk herba meniran diayak dengan pengayak 100 mesh. Sebanyak 250 gram serbuk herba meniran dimaserasi dengan 1000 $\mathrm{mL}$ pelarut etanol $96 \%$ selama 24 jam dan dilanjutkan dengan remaserasi dengan 1000 $\mathrm{mL}$ pelarut etanol $96 \%$ selama 24 jam. Maserat yang diperoleh dihitung volumenya dan diuapkan pelarutnya dengan rotary evaporator pada suhu $40^{\circ} \mathrm{C}$ hingga diperoleh ekstrak kental.

\section{Standarisasi Ekstrak Herba Meniran}

Standarisasi ekstrak herba meniran meliputi perhitungan kadar air, penetapan kadar abu total, penetapan kadar abu tidak larut asam dan penetapan kadar flavonoid total.

\section{Perhitungan Kadar Air}

Uji kadar air dilakukan dengan metode gravitimetri. Dimasukkan 10 gram zat danditimbang dalam wadah yang telah ditara, dikeringkan pada suhu $105^{\circ} \mathrm{C}$ selama 5 jam dan ditimbang. Dilanjutkan dengan pengeringan dan ditimbang pada jarak 1 jam sampai perbedaan antara dua penimbangan berturut-turut tidak lebih dari $0,25 \%$. Kadar 
air dihitung dalam \% v/b (DepKes RI, 1995). Dimana kadar air untuk ekstrak herba meniran tidak lebih dari 17\% (DepKes RI, 2008).

\section{Penetapan Kadar Abu Total}

Sebanyak 3 gram ekstrak yang telah digerus dan ditimbang seksama, dimasukkankedalam krus silikat yang telah dipijarkan dan ditara, diratakan. Pijarkan perlahan-lahan hingga arang habis dinginkan dan timbang. Jika cara ini arang tidak dapat dihilangkan, tambahkan air panas, saring kertas saring bebas abu. Pijarkan sisa dan kertas saring dalam krus yang sama. Masukkan filtrat kedalam krus, uapkan, pijarkan hingga bobot tetap, timbang, hitung kadar abu terhadap bahan yang telah dikeringkan di udara (DepKes RI, 2000). Dimana standarisasi kadar abu total untuk ekstrak herba meniran tidak lebih dari 3,5\% (DepKes RI, 2008).

\section{Penetapan Kadar Abu Tidak Larut Asam}

Abu yang diperoleh pada penetapan kadar abu, dididihkan dengan $25 \mathrm{~mL}$ asam sulfat encer $\mathrm{P}$ selama 5 menit, kumpulkan bagian yang tidak larut dalam asam, kemudian saring melalui krus kaca masir atau kertas saring bebas abu, cuci dengan air panas, pijarkan hingga bobot tetap, timbang. Lalu hitung kadar abu yang tidak larut dalam asam terhadap bahan yang telah dikeringkan diudara (DepKes RI, 2000). Dimana standarisasi kadar abu tidak larut asam untuk ekstrak herba meniran tidak lebih dari 1,5\% (DepKes RI, 2008).

\section{Penetapan Kadar Flavonoid Total}

\section{Pembuatan Kurva Standar Kuersetin}

Kuersetin ditimbang sebanyak $25 \mathrm{mg}$ dimasukkan kedalam labu ukur $25 \mathrm{~mL}$, kemudian ditambahkan etanol $80 \%$ sampai 25 $\mathrm{mL}$ (larutan induk $1000 \mu \mathrm{g} / \mathrm{mL}$ ). Kemudian dibuat serangkaian larutan standar $20 \mu \mathrm{g} / \mathrm{mL}$, $40 \mu \mathrm{g} / \mathrm{mL}, 60 \mu \mathrm{g} / \mathrm{mL}, 80 \mu \mathrm{g} / \mathrm{mL}$ dan 100 $\mu \mathrm{g} / \mathrm{mL}$. Dipipet masing-masing sejumlah 0,5 $\mathrm{mL}$ dari larutan standar ditambah dengan 1,5 $\mathrm{mL}$ etanol $95 \%, 0,1 \mathrm{~mL}$ aluminium klorida (AlCl3) 10\%, 0,1 mL kalium asetat $1 \mathrm{M}$ dan ditambahkan akuades 2,8 mL. Setelah itu diinkubasi selama 30 menit pada suhu $25^{\circ} \mathrm{C}$. Serapannya diukur pada $\lambda \quad 434,2 \quad \mathrm{~nm}$ menggunakan spektrofotometer Uv-Vis.
Kemudian dibuat kurva kalibrasi dengan menghubungkan nilai serapan sebagai koordinat (Y) dan konsentrasi larutan standar sebagai absis (X) (Azizah dkk., 2014).

Pembuatan Larutan Uji Ekstrak Herba Meniran

Ekstrak herba meniran diambil 5,0 g kemudian ditambah $25 \mathrm{~mL}$ etanol. Kemudian diaduk selama 24 jam menggunakan alat pengaduk pada kecepatan $200 \mathrm{rpm}$, kemudian disaring dan filtrat yang diperoleh ditambah etanol sampai $25 \mathrm{~mL}$ (Azizah dkk., 2014).

Penentuan Kadar Flavonoid

Larutan blanko dibuat dengan mengganti larutan standar dengan etanol 0,5 $\mathrm{mL}$. Ditambah dengan 1,5 mL etanol 95\%, 0,1 $\mathrm{mL}$ aluminium klorida (AlCl3) $10 \%, 0,1 \mathrm{~mL}$ kalium asetat $1 \mathrm{M}$ dan ditambahkan akuades 2,8 mL. Setelah itu diinkubasi selama 30 menit pada suhu $25^{\circ} \mathrm{C}$. Setiap pengukuran serapan dibandingkan terhadap blanko. Larutan uji berisi 1,0 mL ekstrak etanol herba meniran dipipet, kemudian ditambah etanol sampai 10 $\mathrm{mL}$ dalam labu ukur. Sejumlah $0,5 \mathrm{~mL}$ larutan kemudian ditambah dengan $1,5 \mathrm{~mL}$ etanol 95\%, 0,1 mL aluminium klorida $(\mathrm{AlCl} 3) 10 \%$, $0,1 \mathrm{~mL}$ kalium asetat $1 \mathrm{M}$ dan ditambahkan akuades 2,8 mL. Setelah itu diinkubasi selama 30 menit pada suhu $25^{\circ} \mathrm{C}$. Serapannya diukur pada $\lambda \quad 434,2 \quad n m$ menggunakan spektrofotometer Uv-Vis. Pengujian dilakukan secara triplo. (Azizah dkk., 2014). Dimana kadar flavonoid total untuk simplisia herba meniran tidak kurang dari 3,20\% dihitung sebagai kuersetin (DepKes RI, 2008).

\section{Pembuatan Sediaan}

Ditimbang bahan-bahan secara seksama dan botol sediaan ditera $60 \mathrm{~mL}$. Kemudian dibuat sirupus simpleks dengan melarutkan sukrosa dengan aquades didalam beaker glass diatas hot plate. Kemudian dilarutkan nipagin dalam propilenglikol secukupnya (Campuran I), ekstrak herba meniran dilarutkan dengan sisa propilenglikol hingga larut, selanjutnya ditambahkan dengan campuran I dan sirupus simpleks secukupnya hingga semua bahan terlarut. Campuran ditambahkan essence anggur, kemudian sediaan dimasukkan kedalam botol dan ditambahkan sisa sirupus simpleks hingga volumenya $60 \mathrm{~mL}$. 


\section{HASIL DAN PEMBAHASAN}

\section{Standarisasi Ekstrak Herba Meniran}

Ekstrak kental herba meniran adalah ekstrak yang dibuat dari herba Phyllanthus niruri L., suku Euphorbiaceae.

\begin{tabular}{ll}
\hline \multicolumn{1}{c}{$\begin{array}{c}\text { Uji Standarisasi } \\
\text { Ekstrak }\end{array}$} & Hasil \\
\hline Kadar Air & $7,295 \%$ \\
Kadar Abu Total & $3 \%$ \\
Kadar Abu Larut Asam & $1,2 \%$ \\
Kadar Flavonoid Total & $3,15 \%$ \\
\hline
\end{tabular}

\section{Standarisasi Ekstrak Herba Meniran}

\section{Uji Kadar Air}

Pengukuran kadar air dari ekstrak kental yang didapat dilakukan dengan metode gravimetri. Kadar air adalah pengukuran kandungan air yang berada dalam bahan yang bertujuan untuk memberikan batasan minimal atau rentang tentang besarnya kandungan air dalam bahan. Kadar air dihitung dalam \%v/b (DepKes RI, 1995), kadar air yang diperoleh adalah 7,295\%, hasil ini sesuai dengan persyaratan kadar air untuk ekstrak herba meniran, dimana kadar air yang diperuntukkan tidak lebih dari 17\% v/b (DepKes RI, 2008).

\section{Uji Kadar Abu Total}

Pengujian kadar abu total dilakukan dengan tujuan untuk mengetahui kadar abu dari ekstrak meniran telah memenuhi parameter standar mutu yang telah ditetapkan. Kadar abu yag dihitung adalah kadar abu terhadap bahan yang telah dikeringkan di udara (DepKes RI, 2000). Kadar abu total yang diperoleh sebesar 3\%, dimana hasil ini sesuai dengan literatur untuk ekstrak herba meniran kadar abu total tidak lebih dari 3,5\% (DepKes RI, 2008).

\section{Uji Kadar Abu Tidak Larut Asam}

Pengujian kadar abu tidak larut asam dilakukan dengan mendidihkan abu yang telah diperoleh dengan asam sulfat encer $P$ kemudian bagian tidak larut asam dikumpulkan dan disaring melalui krus kaca masir atau kertas saring bebas abu, cuci dengan air panas, pijarkan hingga bobot tetap, timbang. Lalu hitung kadar abu yang tidak larut dalam asam terhadap bahan yang telah dikeringkan diudara (DepKes RI, 2000), kadar abu tidak larut asam yang diperoleh sebesar $1,2 \%$. Hasil yang diperoleh sesuai dengan literatur bahwa kadar abu tidak larut asam ekstrak herba meniran tidak lebih dari $1,5 \%$ (DepKes RI, 2008).

\section{Uji Kadar Flavonoid Total}

Pengujian kadar flavonoid total dilakukan untuk mengetahui kadar flavonoid yang terkandung dalam ekstrak. Perhitungan terhadap kadar flavonoid dilakukan karena kandungan kimia yang berperan sebagai immunomodulator alami adalah flavonoid yang dihitung sebagai kuersetin. Kadar flavonoid total yang diperoleh sebesar 3,15\% dihitung sebagai kuersetin, dimana hasil ini sesuai literatur bahwa kadar flavonoid total ekstrak herba meniran tidak kurang dari 3,20\% dihitung sebagai kuersetin (Depkes RI, 2008).

\section{Uji Evaluasi Sediaan}

1. Uji organoleptis yaitu sediaan sirup berwarna ungu pekat dengan aroma anggur yang khas.

2. Bobot jenis sediaan sirup adalah 1,2482 gram $/ \mathrm{mL}$.

3. Uji volume terpindahkan hasil yang didapat pada percobaan ke-1 sebanyak 58 $\mathrm{mL}$, percobaan ke-2 sebanyak $59 \mathrm{~mL}$. percobaan ke-3 sebanyak $57 \mathrm{~mL}$. Hal ini menunjukkan bahwa sediaan tersebut telah memenuhi persyaratan dimana volume yang terpindahkan tidak kurang dari $95 \%$ volume yang dinyatakan dalam etiket.

4. Uji $\mathrm{pH}$ sediaan yang terukur adalah sebesar 5,52. Nilai pH sediaan sirup sudah sesuai dengan nilai $\mathrm{pH}$ yang dipersyaratkan, dimana nilai $\mathrm{pH}$ yang dianjurkan untuk sirup adalah berkisar antara pH 4-7 (DepKes RI, 1995).

5. Uji viskositas 
Kurva Hubungan Rate of Shear dengan Shearing Stress

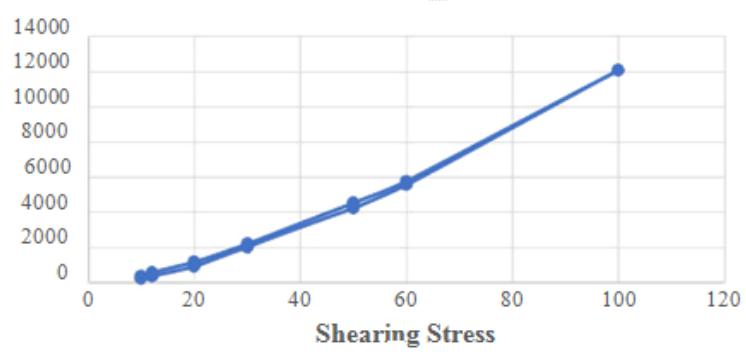

Gambar 1. Kurva Hubungan Rate of Shear dengan Shearing Stress

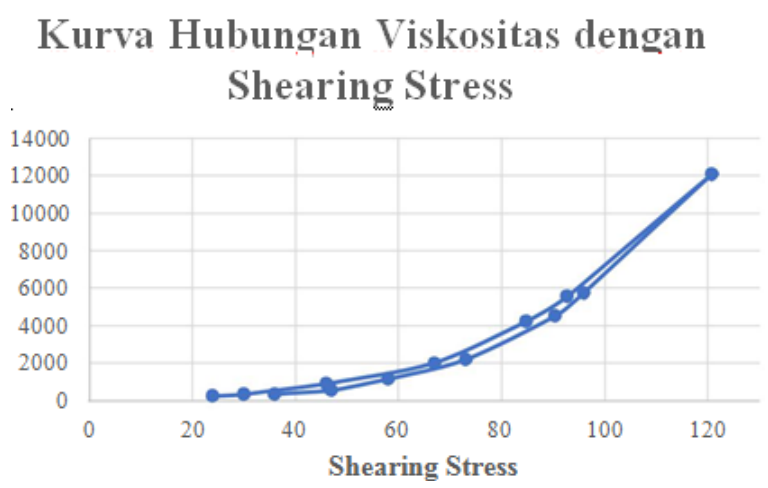

Gambar 2. Kurva Hubungan Viskositas dengan Shearing Stress

Rheogram yang diperoleh menunjukkan bahwa sediaan yang telah direkonstitusi memiliki sifat alir pseudoplastik. Hal ini menunjukkan bahwa sediaan yang dibuat memenuhi persyaratan dimana sediaan farmasi sebagian besar mengikuti sifat aliran NonNewton pseudoplastik yaitu tipe sifat alir yang akan menurun dengan meningkatnya kecepatan geser.

\section{KESIMPULAN}

Hasil standarisasi ekstrak herba meniran menunjukkan bahwa ekstrak herba meniran yang diperoleh telah memenuhi parameter standar mutu ekstrak herba meniran FHI berdasarkan parameter uji kadar air, parameter uji kadar abu total, parameter uji kadar abu tidak larut asam dan parameter uji kadar flavonoid total, sehingga ekstrak herba meniran dapat digunakan sebagai bahan dalam produk farmasi.

\section{UCAPAN TERIMAKASIH}

Ucapan terimakasih ini diucapkan penulis untuk seluruh staf dosen, pegawai dan laboran laboratorium fitokimia Fakultas Matematika dan Ilmu Pengetahuan Alam, Universitas Udayana

\section{DAFTAR PUSTAKA}

Ansel, H. C. 2005. Pengantar Bentuk Sediaan Farmasi, Edisi Keempat. Jakarta: UI Press. Hlm. 327-335; 354-363.

Azizah, D. N., Kumolowati, E., Faramayuda, F. 2014. Penetapan Kadar Flavonoid Metode $\mathrm{AlCl} 3$ Pada Ekstrak Metanol Kulit Buah Kakao (Theobroma cacao L.). Kartika Jurnal Ilmiah Farmasi. 2(2): 45-49.

Bellanthi dan Joseph, A. 1993. Imunologi III. Jakarta: Pendidikan Tinggi Departemen Pendidikan dan Kebudayaan.. Hal: 203210.

DepKes RI. 1992. Undang-Undang Kesehatan No 23 Tahun 1992. Tentang Kesehatan. Jakarta.

DepKes RI. 1995. Farmakope Indonesia. Edisi IV. Jakarta: Departemen Kesehatan Republik Indonesia. Hal. 847-848; 854$855 ; 1030 ; 1039$.

DepKes RI. 2000. Parameter Standar Umum Ekstrak Tumbuhan Obat. Cetakan Pertama. Jakarta: Departemen Kesehatan Republik Indonesia.

DepKes RI. 2008. Farmakope Herbal Indonesia. Edisi I. Jakarta: Departeman Kesehatan Republik Indonesia.

Menkes RI. 1994. Keputusan Menteri Kesehatan Republik Indonesia Nomor: 661/Menkes/SK/VII/1994 Tentang Persyaratan Obat Tradisional. Jakarta: Menteri Kesehatan Republik Indonesia.

Mondal, S et al. 2011. Double-Blinded Randomized Controlled Trial for Immunomodulatory Effects of Tulsi (Ocimum sanctum Linn.) Leaf Extract on Healthy Volunteers. J. Ethnopharmacol. $1-5$.

Puspitasari, D. 2010. Efek Perseptif Meniran (Phyllanthus niruri L.) sebagai Imunostimulan. Skripsi. Depok: Fakultas Matematika dan Ilmu Pengetahuan Alam Departemen Farmasi Universitas Indonesia. 
Roitt, I. M. 1990. Pokok-pokok Ilmu Kekebalan. Jakarta: PT. Gramedia Utama.

Ross, I. A. 1999. Medicinal Plants of the World, Chemical Constituents, Traditional and Modern Medicinal Uses. New Jersey: Humana Press.

Rowe, R. C., Sheskey P.J., dan Quinn M.E. 2009. Handbook of Pharmaceutical Excipients Sixth Edition. London: Pharmaceutical Press.

Sjahrurachman A., N. Sukmana, S. Setiati, Z Munazir, H. Rubiana, L. Nelwan, dan
Dianiati. 2004. Pemberian Terapi Imunomodulator Herbal. Jurnal HTA Indonesia. Hal: 37-40.

Tizard, I. R. 2000. Immunology: An Introduction. 6th Ed. New York: Saunders College Publishing. pp. 98 161.

Voigt, R.1995. Buku Pelajaran Teknologi Farmasi. Yogyakarta: UGM Press.

Wiedosari, E. 2007. Peranan Imunomodulator Alami (Aloe Vera) dalam Sistem Imunitas Seluler Dan Humoral. Wartazoa. 17(4):165-171. 